\title{
"I Found a Fit": Doctoral Student Narratives of Coming to a Theoretical Home in a Qualitative Research Class
}

\author{
Kathleen deMarrais ${ }^{1}$, Lauren Moret $^{2} \&$ Elizabeth M. Pope ${ }^{3}$ \\ ${ }^{1}$ Department of Lifelong Education, Administration, and Policy, University of Georgia, USA \\ ${ }^{2}$ University of Tennessee, Knoxville, USA \\ ${ }^{3}$ Educational Research, University of West Georgia, USA \\ Correspondence: Lauren Moret, Assistant Professor of Qualitative Research Methodology, Educational Psychology \\ \& Counseling Department, University of Tennessee, Knoxville, TN 37996-3452, USA.
}

Received: May 15, 2018

doi:10.5430/irhe.v3n2p83
Accepted: May 30, 2018

Online Published: June 9, 2018

\begin{abstract}
A critical aspect of learning qualitative research methodology in a doctoral program is to develop deep knowledge of the theoretical frameworks informing one's research. An in-depth reading of those theories is necessary for them to be used to inform and guide dissertation research. Based in narrative inquiry, this study examined the journeys of 18 novice qualitative researchers as they came to understand theory and develop a theoretical home to inform their doctoral research. Findings include 1) the emotional concerns, uncertainty, and confusion when asked to engage with theory and theoretical frameworks to inform their research for the first time; 2) supports and strategies used to engage deeply with theories; and 3) students' use of metaphors to describe their relationships with theories over the course of their doctoral studies as they came to a "theoretical home". Implications for doctoral training in qualitative research include the need to engage pedagogically with students around the complexities and messiness of the role of theory in research.
\end{abstract}

Keywords: doctoral education, theoretical frameworks, narrative inquiry

"Qualitative research is very painful! Finding one's theoretical framework in qualitative inquiry is no less than Hercules' task!"

(Alex's Personal Narrative)

\section{Introduction}

Every year, faculty in doctoral programs welcome students anticipating they that will become the future scholars and knowledge creators in universities, community agencies, and corporate settings. As part of their formal coursework and informal engagement with students, faculty serve as guides and mentors as these neophyte researchers learn to engage with theory and research methodologies in their pursuit of doctoral education. While research on teaching and learning in doctoral education is growing, there are still few investigations of how doctoral education programs teach students to use theory to inform their research (Lesko, Simmons, Quarshie, \& Newton, 2008). Little is known regarding how doctoral students come to understand theory, different theoretical perspectives, and the process they go through when identifying and articulating the theoretical framework(s) integrated into their doctoral research. A better understanding of how students learn and use theoretical perspectives, while navigating the doctoral journey, can inform college and university faculty as they prepare students for academic careers.

To further our understandings of how doctoral students in qualitative research courses engaged with theory, we used a narrative inquiry to document their journeys. The overall purpose of this study was to engage qualitative research doctoral students in reflective narratives of how they came to understand theory and theoretical frameworks to inform their doctoral research and dissertation studies. Within the context of a course-based qualitative research program, which emphasized the role of theory, we were particularly interested in learning how students grappled with theory and came to understand which theories best informed their research. Specifically, two research questions informed this study: 1) How do students narrate their experiences of learning about theory and theoretical 
frameworks? 2) How do students craft a theoretical framework to inform their doctoral research? We invited doctoral students enrolled in a narrative inquiry course to participate in this narrative study. Eighteen students in different social science disciplines volunteered to participate in the study, where they recounted personal stories of how they came to their theoretical home(s), the framework of choice to be used for their dissertation research.

We begin this paper with a discussion of literature related to the research preparation of doctoral students, move to the pedagogical context in which the study took place, describe our research methods, then present the following key findings: 1) students' initial introductions to theoretical concepts; 2) supports and strategies students used for understanding theoretical frameworks; 3) students' use of metaphors to describe their relationships with theories over the course of their doctoral studies; and 4) students' reflections on creating and sharing theoretical narratives. We conclude with a discussion and implications for future research and pedagogy within qualitative research courses and programs.

\section{Literature Studied and Area Descriptions}

Doctoral studies are unlike any other academic pursuit (Hawley, 1993). Over the years, there have been increasing interest in the preparation of doctoral students to be successful as students, scholars, and in their future careers (e.g., renewed calls for standards and rigor in research, research that will inform educational practice and policy) (Baltrinic, Jencius, \& McGothlin, 2016; Edwards, Powers, Thompson, \& Rutten-Turner, 2014; Porter \& Phelps, 2014) While there is literature on varying aspects of doctoral preparation across the disciplines, including the supervision of doctoral research (Cavkaytar, 2014; Kamler \& Thomson, 2006; Kayama, 2012; Lee, 2008), development of doctoral student identity (Sweitzer, 2009), suggestions for reshaping the future of doctoral preparation and coursework (Lee \& Danby, 2012; Lesko, Simmons, Quarshie, \& Newton, 2008), and recommendations for ways to improve this preparation (c.f., Boote \& Beile, 2005; Boud \& Lee, 2009; Mendoza \& Gardner, 2010; Golde, 2007; McAlpine \& Amundsen, 2011), research related to our study falls within the following categories discussed next; (1) the student socialization process; (2) transition from graduate student to independent scholar; (3) expected knowledge of doctoral students; (4) using metaphors to describe the doctoral process; and (5) teaching qualitative research to doctoral students.

\section{Socialization and Doctoral Success}

Doctoral student socialization emphasizes the importance of relationship building with peers and professors, while navigating the academic landscape (Noonan, 2015; Russell, 2015; Russell, Gaudreault, \& Richards, 2016; Weidman et al., 2001). Socialization, Gardner (2008) summarized, is "the process through which an individual learns to adopt the values, skills, attitudes, norms, and knowledge needed for membership in a given society, group, or organization" (p. 329). Gardner (2008) identified five themes (ambiguity, balance, independence, development and support) that could lead to a successful transition from doctoral student to scholar (pp. 731-741). Jazvac-Martek (2009) argued doctoral students felt like academics "when they each enacted or projected academic role identities and this was accepted or confirmed by those with whom they interact, including other faculty, professors, and colleagues" (p. 260). Thus, it is through a scholarly community of peers and more senior academics that doctoral students transition from merely being students to becoming scholars in their own right.

Weidman, Twale, and Stein (2001) and Weidman and Stein (2003) offered a non-linear socialization framework that addressed individual relationships with the communities of faculty, students, and programmatic structures to encourage a culture supportive of effective socialization into the professions. The authors suggested that specific strategies (e.g., peer and faculty mentoring and publishing, organizational support) created the supportive climate needed for future academic and/or research careers. Noonan (2015) added that specific research and writing strategies within an academic community can create independence and confidence which in turn leads to the development of a scholarly identity. Roulston, Preissle, and Freeman (2013) argued that this social network was reminiscent of a community of practice and played a role in the socialization of doctoral students as well as in the development of their research agendas (p. 263).

\section{Transitioning from Student to Scholar}

What is success in doctoral education? In Gardner's (2009) study, students reported having a hard time making the transition from doctoral student to independent scholar which involved a shift "from being consumers of knowledge...to creators of knowledge" and occurred at different times for different students (Gardner, 2008, p. 328). Without the proper supports in place, something that varies for everyone, such a shift is difficult to navigate. The shift from doctoral students planning for careers as faculty can be challenging because the process of "doctoral becoming" is comprised of "uncertainty, doubt, trial, and error...as an integral part of the learning process, without 
which higher-level skills in autonomous critical thinking and research scholarship would not be achieved" (Ali Zeilani, Al-Nawafleh, \& Evans, 2011, p. 364). The shift of becoming is compounded with defining a theoretical framework in which to situate their dissertation studies. Asking these questions: How do graduate students navigate their way to a theoretical home? How do graduate students understand their learning experiences duringthis journey? may provide a more nuanced understanding of how doctoral students develop into scholars.

\section{Expected Knowledge of Doctoral Students}

Hample (2008) invited three authors to contribute perspectives on what new PhDs in their respective fields should know. Hample noted that teaching students "to specialize and to deepen collective understandings" regarding a given topic is a key task of doctoral education (p. 111). Integral to developing a deep understanding of any given topic is having a relationship with and/or an understanding of theoretical concepts used to study that subject (Hample, 2008). Roloff (2008) argued students "gain appreciation of the assumptions underlying their approach and methods, as well as knowledge about how to construct theory" through coursework (p. 115). Alternatively, Wisker (2015) found that it is during the literature review that students gained confidence with a theoretical framework. For Wisker (2015), a good literature review revealed this knowledge and suggested it was a "conceptual threshold crossing" because it was "in the very struggles with articulation...that the author can show they have something to say about a breakthrough and standpoint offered by their work" (p. 68). Coursework and the dissertation process inundate doctoral students in both the theoretical and empirical literature of their field, teaching students how to engage with the scholarly conversation and how to contribute to current scholarship through their own voice.

Pfau (2008) noted many mass communication doctoral students were "deficient in their knowledge of epistemological traditions other than their own chosen way of knowing" and, as a result, "scholars are not in a position to utilize relevant knowledge generated from alternative epistemologies and methodologies and are often unable to even read all the relevant research" (p. 121). Putnam (2008) described young scholars as needing to "know the theoretical arenas that emanate from research within the field" (p. 129). Knowing all potential theoretical concepts and frameworks used within a given field of expertise seems to be critical in doctoral education. Yet, there is limited information about the process doctoral students go through as they learn relevant theories and concepts to guide their research.

\section{Using Metaphors to Describe their Process}

In writing about doctoral education, scholars used metaphors to describe students' processes such as metaphors of travel, space, and being (Miller, 2004). Some described the task as similar to traveling through "a perilous passage" (Hadjiouannou, Shelton, Fu, \& Dhanarattigannon, 2007), while others portrayed the process of learning doctoral research as wandering in a state of confusion (Miller, 2004). Angelique, Kyle, and Taylor (2002) depicted the state of being as a doctoral student as dystopian. Others compared the process of learning to research to horror films (Lesko, Simmons, Quarshie, \& Newton, 2008). The use of metaphor is an important way for doctoral students and scholars of doctoral education to understand the process of study and the development of research skills. The use of metaphor can be a way of "sharing key concepts with wider audiences" for both students and scholars (Barrett \& Hussey, 2015, p. 55).

Using literary creativity in ways such as with metaphor can be difficult for some students. Yet Noonan (2015) reported when doctoral students creatively approached their research they gained "confidence by experimenting with ideas through novel learning experiences and interdisciplinary modes of inquiry" (p. 20). While this approach may be difficult for some students, experimenting with the "interaction of ideas, language and visualisations" can be a way to promote creative and critical thinking and strengthen connections with conceptual frameworks (Barrett \& Hussey, 2015, p. 55). Creative thinking and the use of metaphor were a representation of student engagement for Baptista and Huet (2012) and symbolized their process of learning and absorption of knowledge on their paths to becoming academics.

\section{Teaching Qualitative Research to Doctoral Students}

The literature on teaching doctoral students qualitative research has grown over the years, with emphases on teaching methodological rigor (Anfara, Brown, \& Mangione, 2002; Preissle \& deMarrais, 2011, 2015; Preissle \& Roulston, 2009), learning how to conduct research, report findings, and thus become a qualitative researcher (Breur \& Schreier, 2007; Caffarella \& Barnett, 2000; Carawan, Knight, Wittman, Pokorny, \& Velde, 2011; DeLyser \& Potter, 2013), and using visual and non-traditional research and teaching methods to advance the field (Holm, 2008; Hsiung, 2016; McAllister \& Rowe, 2003). Yet, as Jazvac-Martek (2009) reported, "rarely considered are student intentions, motivations, or the variability of experiences and interactions that influence shifting identities" as an independent 
academic ( $\mathrm{p}$ 254). Additionally, there is limited literature addressing "how novice researchers describe in detail the development of topics for dissertation studies" (Roulston, Preissle, \& Freeman, 2013, p. 254). Research on students' perspectives as they go through the process of learning to become skilled researchers and successful academics could have implications for support strategies to improve the transition from student to scholar.

Pergert (2009) described how students were unsure of how to link theory to methodology when learning grounded theory and that "many candidates displayed misunderstanding $[\mathrm{s}]$ of the research functions for conceptual frameworks" (p. 289). What is more, with regard to talking about paradigms and conceptual frameworks, Leshem (2007) found doctoral candidates were hesitant and "reluctant to expose their 'ignorance'," (p. 292). This is where socialization with a cohort of students or with faculty as mentors (Kayama et al., 2013) becomes important. Leshem (2007) argued the ability of doctoral candidates to improve their understanding and use of conceptual frameworks can increase with support from others through a cohort-based doctoral program. Additionally, Rubenstein-Avila and Maranzana (2015) found that one of the most challenging aspects to teaching qualitative research is teaching students how to "incorporate their subjectivities into their work [and] to engage with the dynamic relationship between self and the larger cultural world" (p. 252), an understanding of which is a key component of the development of a conceptual framework.

In summary, though literature is growing regarding some aspects of the doctoral student experience and an increasing number of studies report the necessity of learning theory as part of this process, there is limited information available on how doctoral students navigate their way through the development of their theoretical framework for doctoral research: yet, the need for identifying a theoretical framework to inform their research is an integral part of the doctoral student experience. Dillow's (2009) description of her own journey describes the struggle with theory and the "need to be scholarly" (p. 1338). She noted, "I have been worrying about theory. I have wrestled with how to fit it in, or how to fit me in." (p. 1338). Clegg (2012) provided reflections on her own practices of research, where a lack of theory to support the data led her to search out theories and ideas from different authors. Clegg (2012) argued for a "greater sociological and epistemological sophistication in understanding how we theorise" (p. 409), believing that "the movement from theory to data and back again is problematic" (p. 409). While Dillow (2009) and Clegg (2012) provide autoethnographic accounts of coming to theory, we still have little empirical understanding of how students come to belong and contribute to an academic milieu (Holbrook \& Johnston, 1999). This study, then, sought to understand how students grapple with theoretical constructs to identify a theoretical home from which to design and implement a qualitative dissertation. We now turn to our research methods.

\section{Research Design and Methods}

This study took place within the context of the University of Georgia's Interdisciplinary Qualitative Studies (IQS) Certificate Program. This program was created in response to the growing demand for qualitative approaches to research and to provide students with methodological training in designing and implementing qualitative research studies. To obtain the IQS Certificate, students complete a series of mandatory and elective courses. We conducted the current study in an elective course titled Narrative Analysis, where students learned about the theory and use of narrative in qualitative research. All students in the course had previously taken Qualitative Research Traditions, a pre-requisite course which provides an in-depth overview of many of the traditions and theoretical frameworks that undergird qualitative research. Many had also taken the second core course, Designing Qualitative Research, which offers students instruction and training in designing qualitative studies and the data generation process.

This study is based on two assignments from the Narrative Analysis course. The first assignment, the student's Personal Theoretical Narrative, required students to construct a narrative based on how they developed the theoretical framework for their own research projects. This assignment instructed students to think metaphorically and narratively about how they came to the theoretical stance(s) they hold. In a second assignment, students engaged with peers within the class on the same topic. They each conducted a narrative-based interview of at least 60 minutes in which they elicited a narrative of their participant's theoretical journey. Using just the following prompt with follow up questions for elaboration, rich narratives were generated: "Tell me about coming to the theoretical framework that informs your research." In this assignment, students further developed and refined their narrative interviewing skills, transcribed the interviews, then constructed narratives representing their interviewee's journeys toward a theoretical home. The narratives used in this study were constructed by the students within the course and thematically analyzed by the authors.

All 18 students in the class agreed to participate in the study by sharing their personal and constructed narratives. Thus, we used purposeful sampling (LeCompte \& Preissle, 1993; Merriam \& Tisdell, 2016) focused on students, who were enrolled in Narrative Analysis course. Participants in the class were both part-time and full-time students, 
all enrolled in PhD programs, and all pursuing the IQS certificate. Table 1 below includes demographic information about each student participant using a pseudonym, such as their gender, field of study, and when they were first introduced to theoretical concepts. All student names in the following sections are pseudonyms.

Table 1. Demographics of narrative study participants using pseudonyms

\begin{tabular}{llll}
\hline Pseudonym & Gender & Field of Study & Initial Introduction to Theory \\
\hline Livie & Female & Recreation and Leisure Studies & Doctoral program \\
Alex & Male & Language and Literacy Education & Doctoral program \\
Mei & Female & Learning, Design, and Technology & Undergraduate program \\
Jada & Female & Sport Management & Undergraduate program \\
Adaline & Female & Mathematics Education & Doctoral program \\
Emily & Female & Art Education & Doctoral program \\
Bree & Female & Student Affairs & Doctoral program \\
Harper & Female & Art Education & Master's program \\
Lindsey & Female & Student Affairs & Master's program \\
Kaitlyn & Female & Language and Literacy Education & As a teacher before doctoral \\
& & & program \\
Daphne & Female & Public Health & Doctoral program \\
Charlotte & Female & Public Health & Master's program \\
Sarah & Female & Language and Literacy Education & Master's program \\
Natalia & Female & Educational Administration and Policy & Master's program \\
Glenn & Male & Science Education & Doctoral program \\
Joseph & Male & Language and Literacy Education & Master's program \\
Yali & Female & Adult Education & Doctoral program \\
Anika & Female & Mathematics and Science Education & Doctoral program \\
\hline & & & \\
\hline
\end{tabular}

We used a two-tiered approach to analyze the data of this study: (1) narrative analysis and (2) thematic analysis. While there is limited to no generalizability in qualitative research (Denzin \& Lincoln, 2018), by using two different forms of analysis methods on our narrative data, we sought credibility, trustworthiness, and truth (Freeman, deMarrais, Preissle, Roulston, \& St. Pierre, 2007) of participants' experiences of coming to a theoretical home from which to write their dissertation.

\section{Narrative Analysis}

We employed a narrative analysis, a method that "opens up forms of telling about experience" to analyze the stories, experiences, and beliefs of the student participants (Riessman, 2000, p. 3). A narrative approach to analysis offers the researcher another's perspective of "what their experience is like, what they believe and how they think" (Cortazzi, 1993, p. 5) and insight into "the struggle and context of lived experience to be seen and heard as it is the type of discourse that draws together diverse events, happenings, and actions of human lives" (Polkinghorne, 1995, p. 5). This narrative approach provides "structure within which to think about our daily lives and about the magic and mess of human possibilities" (Dillow, 2009, p. 1344). Writing a qualitative dissertation can be filled with magical and messy theoretical wanderings.

\section{Thematic Analysis}

Thematic analysis is the most common but "rarely acknowledged" analytic method in qualitative research (Braun \& Clarke, 2006. p. 77). Braun and Clarke (2006) described thematic analysis as a "the first qualitative method of analysis that researchers should learn, as it provides core skills that will be useful for conducting many other forms of qualitative analysis...identifying, analyzing and reporting patterns (themes) within data" (p. 78). Thematic analysis is a foundational analytic method, which incorporates a holistic way of conceptualizing data, allows for 
flexibility, creates clarity, and offers wide applicability. Saldaña (2016) offered the general definition of a theme as "an extended phrase or sentence that identifies what a unit of data is about and/or what it means" (p. 297). Thus, thematic analysis of data allows the researcher to organize units of data within or across data sets into categorized descriptive phrases or sentences that represent aspects of the nature of that data. Thematic analysis is a process involving several steps in which the researcher identifies, organizes, and clusters similar themes together for the final analysis. We follow Braun and Clarke's (2006) steps of familiarization with the data, coding, searching for themes, reviewing themes, defining and naming themes, and writing it up (Braun \& Clarke, 2006).

In this study, a thematic analysis was used as an generative process that allowed the researchers to develop themes throughout an interactive analytic progression. We used an inductive process of open coding and categorization (Saldaña, 2016) to generate the following three primary themes: 1) the emotional concerns, uncertainty, and confusion when asked to engage with theoretical frameworks in their research for the first time; 2) supports and strategies used to engage deeply with theories; and 3) students' use of metaphors to describe their relationships with theories over the course of their doctoral studies.

In the following sections, we provide data from assignments completed by students in the Narrative Analysis course. The narrative portions of the paper are taken directly from the students' assignments with the original formatting retained. Any material that appears in brackets has been added by the researchers for purposes of clarity. Sections coming from the students' own personal narratives are cited as "personal narratives." Sections from the second interview project are cited as "constructed narratives" because they were constructed by the student who interviewed a peer for this second assignment.

\section{Findings}

The 18 student participants in this study were eloquent in their discussions of developing the theoretical frameworks informing their dissertation research. The students' personal narrative essays described emotional responses to initially grappling with theory. They constructed their narratives with notions of a temporal journey comprised of a clear beginning, middle, and end (Clandinin \& Connelly, 2000). The student as the protagonist in these stories was often confronted with the conflict or struggle of understanding abstract social science theories. Students described their challenges and successes navigating theoretical constructs and frameworks. Their narratives often concluded with descriptions of how they overcame challenges and worked their ways toward comfort with those theories.

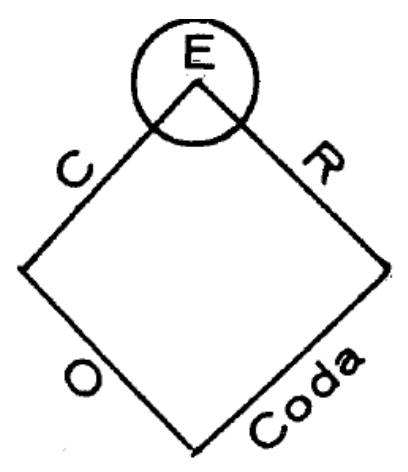

Figure 1. Labov and Waletzky's Normal Form of Narrative

Labov and Waletzky's $(1967 ; 1997)$ narrative structure is useful as an overall visualization of how students told their stories. In this study, the narrative structure first started with the orientation $(O)$ in which students situated themselves within a working theory from their doctoral process; this begins at the base of the diamond in the figure. Second, students described a complication (C) or complicating action related to fit with a theory they tried for their own dissertation work; this has the students moving towards the apex of complication and leading them to resolution. Third, students described a resolution (R) in which they identified and used a theory that helped to resolve the internal conflict they felt, leading to feelings of finding a theoretical home from which to write their dissertation work. Fourth and finally, the narrative structure concluded with an evaluation (E) of strategies and support structures. Among our students' data, the overall coda, concluding remark or ending, drew the narrative to a close and provided a short summary of the students' learning experiences (Riessman, 2008). We turn next to a fuller discussion of the key themes generated across the students' narrative accounts. 


\section{Initial Introductions to Theoretical Concepts}

Students' journeys in developing a theoretical framework began with their first introduction to social science theory. These introductions may have occurred in either their undergraduate, masters, or doctoral programs and were critical to their theoretical learning process. Many students spoke of being unprepared and unable to understand theory in their initial engagement with it in earlier coursework. Faced with introductions to theoretical concepts, they used words like "anxiety," "struggle," "uneasiness," "alarming." and "stressful" to describe their feelings at that point in the process. Some students reported feeling confused or behind their peers in terms of knowing theory, understanding theory, and choosing a theory from which to situate dissertation research. Daphne, a public health educator, described her initial confusion, unpreparedness, and a journey "through the fog" to a better understanding of the role of theory within research:

My first experience with "theory" was total confusion. It was hard for me to understand the reverence and urgency due theory, the underpinning of all worthy research. I tried to avoid thinking about it. After persistent exposures and assistance from patient teachers, the fog is beginning to lift and the importance of theoretical frameworks is clearer to me. (Daphne's Personal Narrative)

Students struggled to learn unfamiliar theoretical language. Adaline's narrative detailed the challenge in learning language specific to particular theories. She expressed lack of clarity and structure in her approach to theory and wanted the professor to provide this for her:

I remember when I was trying to connect what was in the book and trying to connect it with my own unique idea; trying to make sense of it. It seemed that in the book everything was in particular categories and squares, and there were four or five different theories that I had to choose from, like constructivist theory... And, I had very little background on this. I remember thinking, "did I miss a chapter or something?" because everybody seemed to be talking about it like it was the Bible or something. I was not familiar with it. It was like I missed a memo, like I was the odd man out, you know. I remember, maybe it's because I hadn't been in school in twenty years, graduate school in over twenty years, or maybe this Merten's book was well known by everyone in the class. It was just kind of weird, you know, this one could have these certain qualities, and another one could have these certain qualities...they could overlap. So I stayed after class. I was taking a long time to put my books away because I wanted to talk to [the professor] and, I said, "Could you explain to me exactly what you mean by theoretical framework?" That was the first time I'd heard it, you know, that particular night. "I'm just not familiar with what you mean," I said. It was like a language I wasn't privy to. It was a language only certain people knew; I felt very out of the loop. (Adaline's Constructed Narrative)

Other students expressed feelings of being overwhelmed upon first exposure to learning about and talking about theory. Emily, an art educator, reported feeling inadequate and behind her peers in the face of theoretical readings:

My first semester was overwhelming and I felt inadequate; I did not know all of the theorists my peers were talking about. The majority in the class had taken a theory class the previous semester. Things were happening fast - we were reading about both qualitative and quantitative research, my classmates were making connections to philosophers and theories and when I first heard the word epistemology, I thought it was a medical procedure. I felt as if I were the proverbial horse with the carrot hanging in front of me, just out of reach. (Emily's Personal Narrative)

In contrast to the narratives reported above, when students had been exposed to theoretical concepts in other academic programs they felt more comfortable with theory than their peers. For example, Jada reported:

As an undergraduate major in child and family studies with a minor in psychology, I was inundated with theories and paradigms that related to ways of knowing, thinking, behaving, and performing...Student development theory is undergirded by the ideas that development and learning is not context-specific and does not occur in isolation of a social context. Thus, in the classroom, social constructivism as a macro-theoretical home seemed to make sense for me. (Jada's Personal Narrative)

Natalia, a student with a background in philosophy, explained:

I came to understand that I did not have much trouble with situating myself within theoretical frameworks or underlying theories. Having had a (relatively) good background in philosophy and linguistics, they were not hard to understand or to position myself in respect to them...In my master's and doctoral coursework and in my outside-of-class readings, I attempted to learn as much as I can about different theories and frameworks, so when I engage in different types of research, I have enough background knowledge to 
situate the study and move it the right direction. Do I still struggle with setting that direction? Sure, I do. However, I believe that what I learned about all these theories allow[s] me not only to better frame my studies, but also to understand what others have done in their research. (Natalia's Personal Narrative)

These students' narratives portrayed learning about theory as initially confusing and intimidating but with a combination of coursework, engaging with extra resources, and persistent professors to help, they overcame feelings of intimidation regarding engaging with theory. As we detail in the next section, we found students used a variety of strategies and appreciated diverse supports to help them learn theory.

\section{Supports and Strategies for Understanding Theoretical Frameworks}

While at times overwhelming, specific supports can help students overcome challenges and develop their theoretical understandings. For some students, a network of colleagues, courses, and professors supported their learning of theory. For Mei, the guidance of a particular professor helped her master theoretical concepts. She described this professor as the one who "opened the door of my theoretical home" (Mei's Personal Narrative). This professor introduced her to sociocultural theory and "Lantolf and Vygotsky [became] my first two guests in my theoretical home" (Mei's Personal Narrative). Several students commented on the assistance they received from talking about theory with peers. Alex's personal narrative detailed the deep impact a conversation with one of his peers in the language and literacy education program had on the conceptualization of his theoretical framework. For Anika, her faith and spiritual background provided a foundation upon which she built her theoretical home. In her interview, Anika explained how her "spiritual convictions about God's desire for His people to live free and without oppression guided her to build a philosophical foundation of critical ethnography on her theoretical home" (Anika's Constructed Narrative).

Most often, students described how their own background and personal experiences served as a strategy to understand theory. Lindsey explained being interested in interpretivism "because of how [she] viewed society both as the status quo, but also how human experiences are subjectively intertwined throughout situations, experiences, and decisions" (Lindsey's Personal Narrative). Joseph's experiences as a journalist offered him a background through which his "interpretivist lens continued sparkling" into his work in both his master's and doctoral programs (Joseph's Personal Narrative). Adaline wrote about the questions in her practice as a mathematics teacher that spurred her into the world of theory. With this background, she was interested in learning "what it means to learn and how researchers define learning in mathematics education" (Adaline's Personal Narrative). Her courses introduced her to ideas she had never encountered and "helped [her] to become more open to the idea that there are multiple perspectives of how people view mathematics, mathematical learning, and mathematics education" (Adaline's Personal Narrative).

Kaitlyn sought a theoretical framework she could use in her practice as a classroom teacher. She wrote about the importance of theory in solving practical, "real world" problems:

This [funds of knowledge], like the theory of social capital, seemed to fit with my experience in that I saw many of my students bringing in knowledge from their lived experiences and using that to connect to learning in the classroom. I guess that, overall, I am a practical person, and theories that don't have a practical application or that seem not to explain or effect real life change (change that can be seen or actualized in a person's life) don't appeal to me. There are some theories that seem to 'problematize' the world, but offer no solutions to the problems they present. That doesn't seem very useful to me. I don't want to just talk about problems. I want to solve them. (Kaitlyn's Personal Narrative)

Finally, Charlotte's narrative is worth quoting at length as it detailed the cumulative process of developing and owning a theoretical framework for research:

I remember having to put my theoretical orientation into words and on paper for the first time. That night I sat at my computer, hands on the keyboard almost in a trance, hypnotized by the articles, chapters, and books swirling in my head... Still in the trance, I looked over at my bookcase and saw Incidents in the Life of a Slave Girl, which I normally keep amidst my books to pick up and read whenever there is "downtime" (or times when I want to get away from my responsibilities). Looking at this book made me remember the thoughts and questions of meaning that I contemplated at Rutgers and in my Master's program. The words began to flow. They did not flow in a structured, neat manner, but in a choppy, messy way. After reading it over, I realized that, through free writing about my experiences and my thoughts about life, I had described symbolic interaction, with a social constructionist epistemological stance, and included many of my critical thoughts about the dominant discourse that stifles the voices of groups who live in the margins. After 
reading over what I wrote, I remember thinking, "All I had to do was write about how I think and how I view the world." Through the process of formulating my dissertation topic, purpose, and questions, I now see that this theoretical framework is woven into the very fabric of how I think. It is the scholarly version of the questions I posed as an undergraduate student. It is an extension of my thoughts and influences how I make sense of the world. Further, and most importantly, this theoretical framework is only the beginning of how I use my work to influence the types of voices that get heard, the way that people make meaning of who they are, and the social interactions that dictate both. (Charlotte's Personal Narrative)

Whether they had a rocky start with theory or not, the students' narratives typically ended with a resolution of their struggles. Daphne wrote, "After persistent exposures and assistance from patient teachers, the fog is beginning to lift and the importance of theoretical frameworks is clearer to me" (Daphne's Personal Narrative). Students came to rest in a particular theoretical framework or set of theoretical constructs they used to inform their research. There was a sense in many of the narratives of being both externally and internally challenged to tackle difficult theoretical concepts, rejecting some and embracing others. Throughout our review of the narratives we were struck by the many vivid, creative metaphors students used communicate these experiences. We turn next to a discussion of these metaphors.

\section{Metaphors for Theoretical Journeys}

While the narrative assignments did not mention the use of metaphors, students used metaphors to describe the extent to which a particular theoretical framework fit their own understanding of the world. Bree spoke about the fit of an article of clothing to describe how a theory did or did not fit a student or the research topic. For instance, in her interview Bree portrayed a sweater that did not fit:

Bree bought a sweater. She had seen the sweater on others who were her body type, so she figured it would work for her. She saw the sweater online and in stores. This was now going to be her sweater. She took it home, but it just didn't fit. She tried to accessorize it; she tried stretching it. She paired it with different jeans and bottoms, but finally admitted to herself, "I bought a sweater that didn’t fit." (Bree's Constructed Narrative)

Bree described this same tension with fit and theory through metaphor of a pair of shoes. She tried a theory suggested by her supervisor, but did not feel as though it worked saying, "I thought I had tried on pair of shoes three sizes too small, so again it did not fit" (Bree's Personal Narrative). After grappling with multiple theories, Bree found a solution that worked for her saying, "this journey has been rocky, drama-filled, yet fun. It's like I have found the perfect sweater and shoes. Everything just fits" (Bree's Personal Narrative). Bree's excerpts illustrate how the discomfort often associated with wearing too small shoes or clothing was synonymous with attempting to use a theoretical framework not quite right for her or her research.

Students indicated this process of finding a fit between a theoretical framework their dissertation research was a regular part of the research process. Mei's development of a theoretical framework stretched across her master's and doctoral studies. She portrayed the construction of her theoretical home as inviting theorists to be guests in it. She wrote:

Taking classes with different professor[s] who are experts in different fields assisted me to think about guests in my theoretical home... I hope I can be a good hostess who can help my guests feel happy to know each other and have a great dinner. (Mei's Personal Narrative)

Anika's experiences studying abroad influenced the development of her theoretical framework, described as "strengthen[ing] those walls and add[ing] a roof" (Anika's Constructed Narrative). Sarah compared trying on theories to a fairy tale. She explained, "Throughout the semester, I kept trying on each small piece of theory I learned, like Goldilocks looking for the 'just right' porridge" (Sarah's Personal Narrative). Harper likened her process to that of painting. She commented:

For now, I still stand in front of my canvas. Just getting to the point where I can begin to see the outlines of a theoretical framework in my research, I stand poised ready to begin. It's not real until the loaded brush presses firmly against the canvas and the color glides on. Even if the first mark will eventually be covered by subsequent layers or gessoed over completely in a fit of frustration, this is where the journey begins. My journey is in the present, as I write these very words. The black serif text is my paint and the computer screen is my canvas. I am still the anxious and reluctant painter, but I am also the inspired researcher whose engagement in this very narrative has given me the confidence to make the first mark. (Harper's Personal Narrative) 
Other students spoke of the theoretical framework as a puzzle or key to a riddle. We provide Alex's narrative as an example of this descriptor. At first, Alex described feelings of being ill and he wrote, "I had started feeling cold and fever[ed] due to being frustrated with these theoretical issues. I realized that my body shivered from within" (Alex's Personal Narrative). For Alex everything hinged on finding a theory that would fit, allowing all of the other pieces to come together properly. He wrote, "I felt like if I found my theoretical framework, it would be the key to my Ph.D. riddle!" (Alex's Personal Narrative). Once he solved the riddle he would be able to see the theoretical foundation for his dissertation. While many students desired to be "well situated" in their theoretical homes, they understood that theory was not concrete and their theoretical frameworks might change depending on the content under study.

\section{Students' Reflections on Creating and Sharing Theoretical Narratives}

In addition to writing personal narratives and constructing narratives from interviews with their classmates, students were asked to reflect on the process of both interviewing a peer and creating a narrative of that peer's theoretical journey through a doctoral program. They viewed this narrative process as a way to help them become more critical in their work as well as understanding how theoretical frameworks are constructed and used to inform research. Students reported learning from their own experiences and comparing these experiences to those of their classmates. For Yali, this project "inspired [her] to think more deeply and critically about [her] concern for applying narrative method in [her] study" (Yali's Reflection). If instructors provide deliberate and pointed time geared toward reflecting on the process of learning, graduate students may enhance their practice as researchers and scholars.

Students expressed the need for exposure to different types of professors, theories, and practical uses of theory in research work. The participants in this study stressed the importance of learning from faculty in diverse fields to help them come to an understanding of various theoretical concepts useful to frame dissertation research. For instance, Mei reported "my own learning and teaching experiences led me to my theoretical home (Mei's Personal Narrative). A combination of working with various faculty in diverse fields assisted her consideration of her theoretical home. By taking classes with different professors who are experts in different fields assisted me to think about my theoretical home" By providing doctoral students with exposure to various approaches of qualitative research, they may execute informed decisions in crafting theoretical frameworks which may better fit their own strengths, the content of their studies, and the contexts of their inquiries.

Students described theory as a way of understanding individuals' perceptions of life. They viewed the theoretical framework as a way to practice authenticity in representing the voices of their participants and themselves. Students reported developing theoretical frameworks helped them understand their own identities as researchers, as Joseph explained "I might be one person, but I can have many selves" (Joseph's Reflection, emphasis in the original). As Yali explained, theory is not an arbitrary concept or ambiguous concept but "rather it is a way of understanding how we perceive our lives. In other words, theory helps me express my voice in a concrete and accountable way by providing rational reasons and critical evaluation" (Yali's Personal Narrative). Participants believed the appropriate theory can "give voice to my participants and to myself. To this end, theory can be taught and used in a practical way" (Bree's Personal Narrative).

On the practicality of theory, Jada commented, "I liked seeing how these theories held up to real children, adolescents, and families" (Jada's Personal Narrative). Some students described the changing nature of the theoretical framework, such as Emily's desire to reexamine her theoretical frame at a later time to understand how it continues to develop over time. Across the narratives, like Clegg (2012), students came to recognize the ways they fit into theories and the theoretical frameworks that gave them a language to fit within a community of scholars.

\section{Discussion}

The findings above use narratives to examine doctoral students' experiences of their forays into theory. Participant excerpts represent key points about how students respond to the idea of, learn about, and articulate the theoretical frameworks that inform their dissertation research. The narratives here illustrate a range of individual differences in coming to understand theory during the doctoral journey. Many students' initial interactions with theory were filled with confusion and the feeling of missing necessary areas of knowledge. Students who were exposed to theory in their undergraduate and/or master's studies were able to adapt more easily to learning theoretical concepts and generating frameworks in their doctoral program. Others described their need to find theories that could be practically applied to both their work and research lives. These students found more abstract theories less useful, but came to understand theory beyond this binary of abstract vs. practical.

With more experience in coursework focused on theory and qualitative methodologies, the students who felt behind became more comfortable grappling with theoretical constructs. Often difficult emotions were heightened in this 
process of becoming theoretically informed including feelings of confusion, frustration, anger, and later feelings of success in coming to a theoretical home. Several students described their journey metaphorically. These metaphors represented attempts to find a theory that "fit" as similar to finding clothing that fit, a riddle to be solved, or an elusive portion of their own thought process to be understood.

This study addresses questions regarding how doctoral students navigate their studies and introductions with theory and epistemologies. The narratives above represent the nature of such interactions as riddled with pitfalls, conquests, challenges, and successes. These experiences are symbolic of the nature of doctoral education, for it is disruptive at times and is a "form of education that calls into question common sense, or ideological knowledge" (Lesko et al., 2008, p. 1548). This type of learning can feel like an intellectual assault and our study illustrates the nature of the "discomfort" or "pain" (Lesko et. al. p. 1548) that is often involved in the task of learning to use theory in qualitative research. Representing doctoral student's struggle with theory in narrative form makes our contribution particularly useful in that through these narratives we are able to gain an understanding of personal meaning (Polkinghorne, 2007) for doctoral students of what it means to find their theoretical home.

From this study, we learned much that may have an impact on doctoral education in qualitative research and more broadly in the social sciences. These narratives offer an opportunity to understand how doctoral students come to know theory. We offer several pedagogical implications for instructors in doctoral programs. First, students appreciated the time offered for them to reflect on their experiences with learning, using theory, and in developing their theoretical frameworks. Second, the narrative interview assignment allowed students to gain insight into the experiences of their peers leading to feelings of camaraderie and removing the sense of being isolated in their theoretical processes. Third, the recognition for the need to read deeply in theoretical texts became evident for students. Finally, through reflexively interrogating their own theoretical leanings students developed greater understandings of the necessity of theoretical frameworks in research, how theoretical frameworks and methodology of research are intertwined, and the time it takes to generate a theoretical framework that fits the researcher and their study rather than trying to force a theoretical structure that is not quite suitable. As reflective and reflexive learning are important aspects of qualitative research and what Preissle and deMarrais (2015) refered to as qualitative pedagogy, the activities examined in this study may serve other teachers of qualitative research as methods to enhance reflective learning and reflexivity.

This narrative study offers insight into the process doctoral students undergo when determining their theoretical lens and choosing a framework to support their research. Our participants described their initial challenges with theory, what they used to support their learning of theoretical concepts, and illustrated their process through the use of creative metaphors adding an artistic dimension to their expressions. The findings from this study indicate a desire of doctoral students to be comfortable and confident in a theoretical home that genuinely represents their epistemological and ontological outlook as well as a willingness to engage in this struggle. We thus encourage both students and faculty teaching qualitative research to consider both the intellectual and emotional complexities in constructing a theoretical home and use a pedagogy that supports and scaffolds these understandings across the doctoral journey. As McArthur reminded us (2012), "The idea of higher education research as a struggle is important in so many senses: because it is difficult, hard, splendid, challenging, messy, wicked" (p. 429).

\section{References}

Ali Zeilani, R. S., Al-Nawafleh, A.H., \& Evans, C. (2011). Looking back at the doctorate: A qualitative study of Jordanian graduates from $\mathrm{PhD}$ programs in the U.K. Nursing \& Health Sciences, 13(3), 360-365. https://doi.org/10.1111/j.1442-2018.2011.00629.x

American Educational Research Association. (2006). Standards for reporting on empirical social science research in AERA publications. Educational Researcher, 35(6), 33-40.

American Educational Research Association. (2009). Standards for reporting on humanities-oriented research in AERA publications. Educational Researcher, 38(6), 481-486.

Anfara, V. A., Brown, K. M., \& Mangione, T. L. (2002). Qualitative analysis on stage: Making the research process more public. Educational Researcher, 31(7), 28-38. Retrieved from http://www.jstor.org.proxy-remote.galib.uga.edu/stable/3594403

Angelique, H., Kyle, K., \& Taylor, E. (2002). Mentors and muses: New strategies for academic success. Innovative Higher Education, 26(3), 195-209. Retrieved from http://eric.ed.gov/?id=EJ645437

Asher, N. (2001). Beyond "cool" and "hip:" Engaging the question of research and writing as academic Self-woman of color Other. International Journal of Qualitative Studies in Education, 14(10), 1-12. 
https://doi.org/10.1080/09518390010007665

Baker, V. L., \& Pifer, M. J. (2011). The role of relationships in the transition from doctoral student to independent scholar. Studies in Continuing Education, 33(1), 5-17. https://doi.org/10.1080/0158037x.2010.515569

Baltrinic, E. R., Jencius, M., \& McGlothlin, J. (2016). Coteaching in counselor education: Preaparing doctoral students for future teaching. Counselor Education \& Supervision, 55(1), 31-45. https://doi.org/10.1002/ceas.12031

Baptista, A. V., \& Huet, I. (2012). Making sense of metaphors about doctoral students' competencies: Analysis of supervisors“ voices. Cyprus International Conference on Educational Research, 47, 930-937. https://doi.org/10.1016/j.sbspro.2012.06.759

Barrett, T., \& Hussey, J. (2015). Overcoming problems in doctoral writing through the use of visualisations: Telling our stories. Teaching in Higher Education, 20(1), 48-63. https://doi.org/10.1080/13562517.2014.957266

Boote, D.N., \& Beile, P. (2005). Scholars before researchers: On the centrality of the dissertation literature review in research preparation. Educational Researcher, 34(6), 3-15. https://doi.org/10.2307/3699805

Boud, D., \& Lee, A. (Eds.). (2009). Changing practices of doctoral education. New York, NY: Routledge.

Braun, V., \& Clarke, V. (2006). Using thematic analysis in psychology. Qualitative Research in Psychology, 3(2), 77-101. https://doi.org/10.1191/1478088706qp063oa

Brooks, J. J. (2006). Place as relationship partner: An alternative metaphor for understanding the quality of visitor experience in a backcountry setting. Leisure Sciences, 28(4), 331-349. https://doi.org/10.1080/01490400600745852

Brown, B. A. (2006). "It isn't no slang that can be said about this stuff": Language, identity, and appropriating science discourse. Journal of Research in Science Teaching, 43(1), 96-126. https://doi.org/10.1002/tea.20096

Bruer, F., \& Schreier, M. (2007). Issues in learning about and teaching qualitative research methods and methodology in the social sciences. Forum Qualitative Sozialforschung/Forum: Qualitative Social Research, 8(1), Art. 30. Retrieved from http://qualitative-research.net/index.php/issue/view/6

Caffarella, R. S., \& Barnett, B. G. (2000). Teaching doctoral students to become scholarly writers: The importance of giving and receiving critiques. Studies in Higher Education, 25(1), 39-52. https://doi.org/10.1080/030750700116000

Carawan, L. W., Knight, S., Wittman, P., Pokorny, M., \& Velde, B. P. (2011). On becoming a qualitative researcher: A view through the lens of transformative learning. Journal of Teaching in Social Work, 31(4), 387-399. https://doi.org/10.1080/08841233.2011.597671

Cassell, C., \& Symon, G. (2011). Assessing 'good' qualitative research in the work psychology field: A narrative $\begin{array}{lllll}\text { analysis. Journal of } & \text { Occupational }\end{array}$ https://doi.org/10.1111/j.2044-8325.2011.02009.x

Cavkaytar, S. (2014). The process of doctoral dissertation: From the advisor's perspectives. International Journal on New Trends in Education and Their Implications, 5(3), 128-143. Retrieved from http://www.ijonte.org/FileUpload/ks63207/File/13.-cavkaytar.pdf

Clandinin, D. J., \& Connelly, F. M. (2000). Narrative inquiry: Experience and story in qualitative research. San Francisco, CA: Jossey-Bass.

Clarke, V., \& Braun, V. (2013). Teaching thematic analysis: Overcoming challenges and developing strategies for effective learning. The Psychologist, 26(2), 120-123.

Clegg, S. (2012). On the problem of theorizing: An insider account of research practice. Higher Education Research \& Development, 31(3), 407-418. https://doi.org/10.1080/07294360.2011.634379

Cornelissen, J. P., \& Kafouros, M. (2008). Metaphors and theory building in organization theory: What determines the impact of a metaphor on theory? British Journal of Management, 19(4), 365-379. https://doi.org/10.1111/j.1467-8551.2007.00550.x

Cortazzi, M. (1993). Narrative analysis. London, UK: The Falmer Press. 
DeLyser, D., \& Potter, A. E. (2013). Teaching qualitative research: Experiential learning in group-based interviews and coding assignments. Journal of Geography, 112(1), 18-28. Retrieved from http://dx.doi.org.proxy-remote.galib.uga.edu/10.1080/00221341.2012.674546

Denzin, N. K., \& Lincoln, Y. S. (Eds.) (2018). The Sage handbook of qualitative research (5 $5^{\text {th }}$ ed.). Thousand Oaks, CA: Sage.

Dillow, C. (2009). Growing up: A journey toward theoretical understanding. Qualitative Inquiry, 15(8), 1338-1351. https://doi.org/10.1177/1077800409339581

Edwards, J. D., Powers, J., Thompson, A. M., Rutten-Turner, E. (2014). The value of teaching preparation during doctoral studies: An example of a teaching practicum. Academic Leadership Journal in Student Research, 2(2014), 1-12. Retrieved from http://www.eric.ed.gov/contentdelivery/servlet/ERICServlet?accno=EJ1055350

Freeman, M., deMarrais, K., Preissle, J., Roulston, K., \& St. Pierre, E. A. Standards of evidence in qualitative research: An incitement to discourse. Educational Researcher 36(1), 25-32. https://doi.org/10.3102/0013189X06298009

Gardner, S. (2007). "I heard it through the Grapevine": Doctoral Student Socialization in Chemistry and History. Higher Education, 54(5), 723-740. https://doi.org/10.1007/s10734-006-9020-x

Gardner, S. K. (2008). "What's too much and what's too little?": The Process of Becoming an Independent Researcher in Doctoral Education. Journal of Higher Education, 79(3), 326-350. Retrieved from http://www.jstor.org.proxy-remote.galib.uga.edu/stable/25144671

Gardner, S. K. (2009). Conceptualizing success in doctoral education: Perspectives of faculty in seven disciplines. The Review of Higher Education, 32(3), 383-406. Retrieved from http://muse.jhu.edu.proxy-remote.galib.uga.edu/journals/review_of_higher_education/v032/32.3.gardner.html

Golde, C. M. (2007). Signature pedagogies in doctoral education: Are they adaptable for the preparation of education researchers? Educational Researcher, 36(6), 344-351. https://doi.org/10.2307/30133810

Hadjiouannou, X., Shelton, N. R., Fu, D., \& Dhanarattigannon, J. (2007). The road to a doctoral degree: Co-travelers through a perilous passage. College Student Journal, 4l(1), 160-177. Retrieved from http://eds.a.ebscohost.com.proxy-remote.galib.uga.edu/eds/detail/detail?vid=13\&sid=b868c666-261a-41f2-a1d6 -c7c713a58280\%40sessionmgr4005\&hid=4205\&bdata=JnNpdGU9ZWRzLWxpdmU\%3d\#AN=24628946\&db $=\mathrm{s} 3 \mathrm{~h}$

Hample, D. (2008). Issue forum: Breadth and depth of knowledge in communication. Introduction: What should a new PhD know? Communication Monographs, 75(2), 111-135. https://doi.org/10.1080/03637750802088323

Hawley, P. (1993). Being bright is not enough: The unwritten rules of doctoral study. Springfield, IL: C.C. Thomas.

Holbrook, A., \& Johnston, S. (1999). Supervision of postgraduate research in education. Coldstream, Victoria: Australian Association for Research in Education.

Holm, G. (2008). Photography as a performance. Forum: Qualitative Social Research, 9(2), Art. 38. Retrieved from http://www.qualitative-research.net/fqs/

Hsiung, P. C. (2016). Teaching qualitative method: Craft, profession, or bricolage?. In C. Seale, G. Gobo, J. Gubrium, \& D. Silverman (Eds.), Qualitative research practice (pp. 549-560). London: SAGE.

Ibrhim, E., Larke, P. J., Coston, W., Ruthinger, G. A., Standish, H., Sullivan, E., ... Lea, J. (2010). The voices of seven doctoral students: Journeys toward becoming multicultural teacher educators. National Forum of Multicultural Issues Journal, 7(1), 1-19. $\quad$ Retrieved from http://eds.a.ebscohost.com.proxy-remote.galib.uga.edu/eds/pdfviewer/pdfviewer?sid=b868c666-261a-41f2-a1d6 -c7c713a58280\%40sessionmgr4005\&vid=31\&hid=4205

Jaschik, S. (2006, February 16). Why grad students succeed or fail. Inside Higher Ed. Retrieved from http://www.insidehighered.com/news/2006/02/16/grad

Jazvac-Martek, M. (2009). Oscillating role identities: the academic experiences of education doctoral students. Innovations in Education \& Teaching International, 46(3), 253-264. https://doi.org/10.1080/14703290903068862

Kamler, B., \& Thomson, P. (2006). Helping doctoral students write: Pedagogies of supervision. London, UK: Routledge. 
Kayama, M., Gregg, M. F., Asahara, K., Yamamoto-Mitani, N., Okuma, K., Ohta, K., \& Kinoshita, Y. (2013). Mentoring doctoral students for qualitative research: Interviews with experienced nursing faculty in Japan. Journal of Nursing Education, 52(5), 283-289. https://doi.org/10.3928/01484834-20130320-02

Labov, W., \& Waletsky, J. (1967). Narrative Analysis: Oral Versions of Personal Experience. In J. Helm (Ed.). Essays on the Verbal and Visual Arts (pp. 12-44). Seattle: University of Washington Press.

Labov, W. \& Waletzky, J. (1997). Narrative analysis: Oral versions of personal experience. Journal of Narrative \& Life History, 7(1-4), 1997, 3-38. https://doi.org/10.1075/jnlh.7.02nar

LeCompte, M. D., \& Preissle, J. (1993). Ethnography and qualitative design in educational research (2nd ed). New York, NY: Academic Press.

Lee, A. (2008). How are doctoral students supervised? Concepts of doctoral research supervision. Studies in Higher Education, 33(3), 267-281. Retrieved from http://www.informaworld.com.proxy-remote.galib.uga.edu/openurl?genre=article\&id=doi:10.1080/0307507080 2049202

Lee, A., \& Danby, S. (Eds.). (2012). Reshaping doctoral education: International approaches and pedagogies. New York, NY: Routledge.

Leshem, S. (2007). Thinking about conceptual frameworks in a research community of practice: a case of a doctoral programme. Innovations in Education \& Teaching International, 44(3), 287-299. https://doi.org/10.1080/14703290701486696

Lesko, N., Simmons, J., Quarshie, A., \& Newton, N. (2008). Pedagogy of monsters: scary disturbances in a doctoral research preparation course. Teachers College Record, 110(8), 1541-1573. Retrieved from http://www.tcrecord.org.proxy-remote.galib.uga.edu/Content.asp?ContentId=15152

Lovitts, B. E. (2001). Leaving the ivory tower: The causes and consequences of departure from doctoral study. Lanham, MD: Rowman \& Littlefield.

Maxwell, J. (1996). Qualitative research design: An interactive approach. Thousand Oaks, CA: Sage.

McAllister, M., \& Rowe, J. (2003). Blackbirds singing in the dead of night?: Advancing the craft of teaching qualitative research. Journal of Nursing Education, 42(7), 296-303. Retrieved from http://eds.a.ebscohost.com.proxy-remote.galib.uga.edu/eds/pdfviewer/pdfviewer?sid=c94563d1-59c6-4d6f-b76 $1-48 \mathrm{~d} 8 \mathrm{ed} 24850 \mathrm{c} \% 40$ sessionmgr4003\&vid=1\&hid $=4213$

McAlpine, L., \& Amundsen, C. (Eds.). (2011). Doctoral education: Research-based strategies for doctoral students, supervisors and administrators. New York, NY: Springer.

McArthur, J. (2012). Virtuous mess and wicked clarity: Struggle in higher education research. Higher Education Research \& Development, 31(3), 419-430. https://doi.org/10.1080/07294360.2011.634380

Mendoza, P., \& Gardner, S.K. (2010). The Ph.D. in the United States. In Gardner, S.K. \& Mendoza, P. (Eds.), On Becoming a Scholar: Socialization and Development in Doctoral Education. Sterling, VA: Stylus Publishers, LLC.

Merriam, S. B., \& Tisdell, E. J. (2016). Qualitative research: A guide to design and implementation (4th ed). San Francisco, CA: Jossey-Bass.

Mertens, D. M. (2009). Research and evaluation in education and psychology integrating diversity with quantitative, qualitative, and mixed methods. Thousand Oaks, CA: Sage.

Metz, M. H. (2001). Intellectual border crossing in graduate education: A report from the field. Educational Researcher, 30(5), 12-18. Retrieved from http://www.jstor.org.proxy-remote.galib.uga.edu/stable/3594456

Miles, M. B., \& Huberman, A. M. (1984). Qualitative data analysis: A sourcebook of new methods. London, UK: Sage.

Miller, N., \& Brimicombe, A. (2004). Mapping research journeys across complex terrain with heavy baggage. Studies in Continuing Education, 26(3), 405-417. https://doi.org/10.1080/0158037042000265962

Moll, L. C., Amanti, C., Neff, D., \& Gonzalez, N. (1992). Funds of knowledge for teaching: Using a qualitative approach to connect homes and classrooms. Theory Into Practice, 31(2), 132-141. Retrieved from http://www.jstor.org.proxy-remote.galib.uga.edu/stable/1476399 
Navarro, V. (2005). Constructing a teacher of qualitative methods: A reflection. International Journal of Social Research Methodology, 8(5), 419-435. https://doi.org/10.1080/1364557032000232871.

Nettles, M. T., \& Millet, C. M. (2006). Three magic letters: Getting to Ph.D. Baltimore, MD: The Johns Hopkins University Press.

Noonan, M. J., Ballinger, R., \& Black, R. (2007). Peer and faculty mentoring in doctoral education: Definitions, experiences, and expectations. International Journal of Teaching and Learning in Higher Education, 19(3), 251-262. Retrieved from http://www.eric.ed.gov/contentdelivery/servlet/ERICServlet?accno=EJ901298

Noonan, S. J. (2015). Doctoral pedagogy in stage one: Forming a scholarly identity. NCPEA International Journal of Educational Leadership Preparation, 10(21), 1-28. Retrieved from http://www.eric.ed.gov/contentdelivery/servlet/ERICServlet?accno=EJ1060946

Otten, M., \& Geppert, J. (2009). Mapping the landscape of qualitative research on intercultural communication. A hitchhiker's guide to the methodological galaxy. Forum: Qualitative Social Research, 10(1), Art. 52. Retrieved from http://www.qualitative-research.net/index.php/fqs/article/view/1252

Patton, M. Q. (1990). Qualitative evaluation and research methods. Thousand Oaks, CA: Sage.

Pergert, P. (2009). Methodological learning-by-doing: Challenges, lessons learned and rewards. The Grounded Theory Review, 8(2), 65-75. Retrieved from http://groundedtheoryreview.com/2009/06/30/880/

Polkinghorne, D. (1988). Narrative Knowing and the Human Sciences. Albany: State University of New York Press.

Polkinghorne, D. (1995). Narrative configuration in qualitative analysis. In J. Hatch and R. Wisniewski (Eds.), Life history and narrative (pp. 5-23). London, UK: The Falmer Press.

Porter, S. D., \& Phelps, J. M. (2014). Beyond skills: An integrative approach to doctoral student preparation for diverse careers. Canadian Journal of Higher Education, 44(3), 54-67. Retrieved from http://www.eric.ed.gov/contentdelivery/servlet/ERICServlet?accno=EJ1049383

Preissle, J., \& deMarrais, K. (2011). Teaching qualitative research responsively. In N. K. Denzin, \& M. D. Giardina (Eds.), Qualitative inquiry in global crisis (pp. 31-39). Walnut Creek, CA: Left Coast Press.

Preissle, J., \& deMarrais, K. (2015). Teaching reflexivity in qualitative research: Fostering a life style. In N. Denzin \& M. D. Giardina (Eds.), Qualitative inquiry and the politics of research (pp. 189-196). Walnut Creek, CA: Left Coast Press.

Preissle, J., \& LeCompte, M. (1993). Ethnography and qualitative research in educational research (2nd ed.). Bingley, UK: Emerald Group Publishing.

Preissle, J., \& Roulston, K. (2009). Trends and issues in teaching qualitative research. In M. Garner, C. Wagner, \& B. Kawulich (Eds.), Teaching research in the humanities and social sciences (pp. 13-22). Farnham, England \& Burlington, VT: Ashgate.

Pryor, J. (2010). Constructing research questions: Focus, methodology and theorisation. In P. Thompson \& M. Walker (Eds.), The Routledge doctoral student's companion: Getting to grips with research in education and the social sciences (pp. 161-171). New York, NY: Routledge.

Putnam, L. L., \& Department of Communication, University of California-Santa Barbara. (2008). Developing breadth in organizational communication doctoral training. Communications Monographs, 75(2), 127-135. https://doi.org/10.1080/03637750802088323

Riessman, C. K. (2001). Analysis of personal narratives. In J. F. Gubrium and J. A. Holstein (Eds.), Handbook of interview research (pp. 695-710). Thousand Oaks, CA: Sage. Retrieved from http://alumni.media.mit.edu/ brooks/storybiz/riessman.pdf

Riessman, C. K. (2008). Narrative methods for the human sciences. Thousand Oaks, CA: Sage.

Rodgers, C. (2002). Defining reflection: Another look at John Dewey and reflective thinking. Teachers College Record, 104(4), 842-866. Retrieved from http://www.bsp.msu.edu/uploads/files/Reading_Resources/Defining_Reflection.pdf

Roloff, M. E. (2008). What an interpersonal communication scholar should know. In D. Hample (Ed.), Issue forum: Breadth and depth of knowledge in communication. Communication Monographs, 75(2), 112-119. https://doi.org/10.1080/03637750802088323 
Roulston, K., Preissle, J., \& Freeman, M. (2013). Becoming researchers: doctoral students' developmental processes. International Journal of Research \& Method in Education, 36(3), 252-267. https://doi.org/10.1080/1743727X.2013.806469

Rubenstein-Avila, E., \& Maranzana, S. (2015). Dual reflections on teaching and learning of autoethnography: Preparing doctoral students authentically for a career in the academy. Qualitative Research in Education, 4(3), 243-268. https://doi.org/10.17583/qre.2015.1328

Russell, J. A. (2015). Rolling with the punches: Examining socialization experiences of kinesiology doctoral students. Research Quarterly for Exercise \& Sport, 86(2), 140-152. https://doi.org/10.1080/02701367.2014.987907

Russell, J. A., Gaudreault, K. L., \& Richards, K. A. (2016). Doctoral student socialization: Educating stewards of the physical education profession. Quest, 68(4), 439-457. https://doi.org/10.1080/00336297.2016.1234963

Saldaña, J. (2013). The coding manual for qualitative researchers. Thousand Oaks, CA: SAGE.

Sambrook, S., Stewart, J., \& Roberts., C. (2008). Doctoral supervision . . . a view from above, below and the middle! Journal of Further and Higher Education, 32(1), 71-84. https://doi.org/10.1080/03098770701781473

Shulman, L. S., Golde, C. M., Bueschel, A. C., \& Garabedian, K. J. (2006). Reclaiming education's doctorate: A critique and a proposal. Educational Researcher, 35(3), 25-32. https://doi.org/10.2307/3700104

Smallwood, S. (2004, January 16). Doctor dropout. The Chronicle of Higher Education, 59(19), A10-A12. Retrieved from http://chronicle.com/article/Doctor-Dropout/33786

Southerland, S. A., Gadsden, V. L., \& Herrington, C. D. (2014). Editors' introduction: What should count as quality education research? Continuing the discussion. Educational Researcher, 43(1), 7-8. https://doi.org/10.3102/0013189X13519962

Squire, C. (2013). From experience-centered to socio-culturally oriented approaches to narrative. In M. Andrews, C. Squire and M. Tamboukou (Eds.), Doing narrative research (pp. 47-71). London, UK: Sage.

Squire, C., Andrews, M., \& Tamboukou, M. (2008). What is narrative research?. In M. Andrews, C. Squire, and M. Tamboukou (Eds.), Doing narrative research (pp. 1-21). London, UK: Sage.

Sweitzer, V. B. (2009). Towards a theory of doctoral student professional identity development: A developmental networks approach. Journal of Higher Education, 80(1), 1-33. https://doi.org/10.2307/25511088

Vygotsky, L. S. (1978). Mind in society: The development of higher psychological processes (M. Cole, V. John-Steiner, S. Scribner \& E. Souberman, Eds. and Trans.). Cambridge, MA: Harvard University Press.

Walker, G., Golde, C. M., Jones, L., Bueschel, A. C., \& Hutchins, P. (2007). The formation of scholars: Rethinking doctoral education for the Twenty-first century. San Francisco, CA: Jossey-Bass.

Warren, S. (2005). Photography and voice in critical qualitative management research. Accounting, Auditing, \& Accountability Journal, 18(6), 861-882. https://doi.org/10.1108/09513570510627748

Weidman, J. C., \& Stein, E. L. (2003). Socialization of doctoral students to academic norms. Research in Higher Education, 44(6), 641-656. https://doi.org/10.2307/40197334

Weidman, J. C., Twale, D. J., \& Stein, E. L. (2001). Socialization of graduate and professional students in higher education: A perilous passage? San Francisco, CA: Jossey Bass.

Wisker, G. (2015). Developing doctoral authors: Engaging with theoretical perspectives through the literature review. Innovations in Education and Teaching International, 52(1), 64-74. https://doi.org/10.1080/14703297.2014.981841

Young, L. J. (2001). Border crossing and other journeys: Re-envisioning the doctoral preparation of educational researchers. Educational Researcher, 30(5), 3-5. https://doi.org/10.2307/3594454 